\title{
Synthesis of One Double Bond-Inserted Retinal Analogs and Their Binding Experiments with Opsins: Preparation of Novel Red-Shifted Channelrhodopsin Variants
}

\author{
Takashi Okitsu, ${ }^{a}$ Yumiko Yamano, ${ }^{a}$ Yi-Chung Shen, ${ }^{b}$ Toshikazu Sasaki, ${ }^{b}$ Yuka Kobayashi, ${ }^{a}$ \\ Shoko Morisawa, ${ }^{a}$ Takahiro Yamashita, ${ }^{b}$ Yasushi Imamoto, ${ }^{b}$ Yoshinori Shichida,${ }^{c}$ and \\ Akimori Wada*,a \\ ${ }^{a}$ Laboratory of Organic Chemistry for Life Science, Kobe Pharmaceutical University; Kobe 658-8558, Japan: \\ ${ }^{b}$ Department of Biophysics, Graduate School of Science, Kyoto University; Kyoto 606-8502, Japan: and \\ ${ }^{c}$ Research Organization of Science and Technology, Ritsumeikan University; Kusatsu, Shiga 525-8577, Japan. \\ Received November 14, 2019; accepted December 18, 2019
}

In optogenetics, red-shifted channelrhodopsins (ChRs) are eagerly sought. We prepared six kinds of new chromophores with one double bond inserted into the polyene side chain of retinal (A1) or 3,4-didehydroretinal (A2), and examined their binding efficiency with opsins (ReaChR and ChrimsonR). All analogs bound with opsins to afford new ChRs. Among them, A2-10ex (an extra double bond is inserted at the C10C11 position of A2) showed the greatest red-shift in the absorption spectrum of ChrimsonR, with a maximum absorbance at $654 \mathrm{~nm}(67 \mathrm{~nm}$ red-shifted from that of A1-ChrimsonR). Moreover, a long-wavelength spectral boundary of A2-10ex-ChrimsonR was extended to $756 \mathrm{~nm}$, which reached into the far-red region $(710-850 \mathrm{~nm})$.

Key words channelrhodopsin; retinal analog; chromophore; red-shift; optogenetics

\section{Introduction}

Channelrhodopsin-1 (ChR1, 1) was discovered from Chlamydomonas reinhardtii by Nagel et al. in 2002. ${ }^{1)}$ It is a member of the microbial rhodopsin and is a light-gated cation channel. ChR1 consists of the chromophore (all-trans-retinal, 2a) and a seven-transmembrane helix apoprotein (opsin). The retinal covalently binds to the $\varepsilon$-amino group of lysine residue 296 (K296) through a protonated Schiff base (PSB). Upon absorption of light, photoisomerization of retinal from the all-trans to the 13-cis forms occurs with a conformational structure change of the opsin, and then ChR1 activate the membrane with opening the channel and ion transportation (depolarization). Since the first finding of ChR1, plenty of similar channelrhodopsins (ChRs) have been discovered from archaea, bacteria and eukaryotes. ${ }^{2)}$

Recently, a new technique for treatment of cellular perturbation tools called optogenetics has been developed. ${ }^{3-6)}$ Optogenetics is a technology for controlling specific neural activities by light irradiation that arises from the depolarization of ChRs-expressing neural cells. This technique is less invasive compared to the traditional electrode method that affects other cells. Therefore, optogenetics are deemed to be a useful tool to clarify the neural circuits and the mechanism of various neural diseases. ${ }^{7,8)}$ ChRs now used in optogenetics are mostly sensitive to blue-green light (430-550 nm) and bear several limitations, such as low expression levels, ability of depolarization, kinetics (response of excitation and desensitization), spectra response and ion selectivity due to their biological and physical properties. To overcome these problems, several approaches for the development of new ChRs have been achieved. ${ }^{9)}$ Among them, to create the red-shifted ChRs that are sensitive to long-wavelength light is highly attracted because the red-shifted ChRs can not only provide new op- togenetic tools, which were controlled by currently unused wave-length light, but also deeply penetrate the targeted neural tissues without the influence of other tissue components such as water and blood (scattering and absorption light).

One method to create red-shifted ChR is to introduce mutations of the amino acids of opsin and several such achievements have been reported. ${ }^{10-12)}$ Another approach has been to replace retinal with another red-shifted chromophore having a system of extended conjugation. ${ }^{13-15)}$ In connection with our study on development of new red-shifted ChRs, ${ }^{16)}$ very recently we designed and prepared new chromophores in which a one double bond was inserted into the polyene side chain of all-trans-retinal (A1, 2a) and 3,4-didehydroretinal (A2, 2b) at C6-C7, C10-C11 or C14-C15 positions (nomenclature based on retinal numbering), which were named A1-6ex (3a), A26ex (3b), A1-10ex (4a), A2-10ex (4b), A1-14ex (5a) and A214ex (5b) (Fig. 1). All analogs except for 3a were incorporated into $\mathrm{C} 1 \mathrm{C} 2$, which is one of the most widely used $\mathrm{ChR}$ variants in optogenetics (an absorption maximum at $477 \mathrm{~nm}$ ), ${ }^{17)}$ and among the newly created ChRs, A2-10ex-C1C2 showed the longest absorption maximum at $510 \mathrm{~nm}{ }^{18)}$ These results indicated that polyene chain-elongated retinals could be incorporated into the retinal-binding pocket of $\mathrm{C} 1 \mathrm{C} 2$. However, the red-shift value of absorption maximum of A2-10ex-C1C2 was not enough compared to the ideal red-shifted ChRs, whose absorption maxima are required in the near-infrared region $(750-1500 \mathrm{~nm})$. We anticipated that it might be possible to produce the even more red-shifted new ChRs by changing opsins for binding. As other opsins, we chose $\mathrm{ReaChR}^{11)}$ and Chrimson $\mathrm{R}^{19)}$ because their absorption maxima were $61 \mathrm{~nm}$ and $110 \mathrm{~nm}$ red-shifted, respectively, compared to that of $\mathrm{C} 1 \mathrm{C} 2$. Although the data of A2 analogs $(\mathbf{3 b}, \mathbf{4 b}$ and $\mathbf{5 b})$ were already reported in the literature, ${ }^{20)}$ we describe here a full ac- 
count of the synthesis of six kinds of chromophores and their binding experiments with other opsins.

\section{Chemistry}

With the exception of $\mathbf{5 a},{ }^{21)}$ our designed one double bond elongated retinal analogs $\mathbf{3}-\mathbf{5}$ had been unknown. We therefore planned a systematic synthetic route for 3-5 from the known aldehydes: a 3-step sequence of Horner-WadsworthEmmons reaction/reduction/oxidation (Chart 1). The first step of the Horner-Wadsworth-Emmons reaction with aldehyde using triethyl phosphonoacetate (C2-phosphonate) or triethyl 3-methyl-4-phosphonocrotonate (C5-phosphonate) would af-<smiles>[CH2][NH+]=C/C=C(C)/C=C/C=C(C)/C=C/C1=C(C)CCCC1(C)C</smiles>

1: channelrhodopsin-1 (ChR1)<smiles>CC1=C(/C=C/C(C)=C/C=C/C(C)=C/C=O)C(C)(C)CCC1</smiles>
2a: retinal $(A 1)$<smiles>CC1=C(/C=C/C(C)=C/C=C/C(C)=C/C=O)C(C)(C)CC=C1</smiles>

2b: 3,4-didehydroretinal (A2)

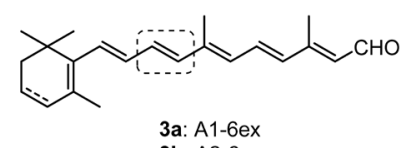

3b: A2-6ex

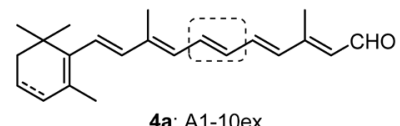

4a: A1-10ex

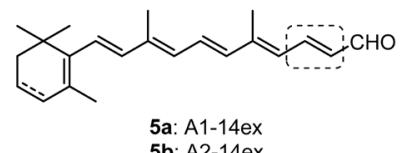

Fig. 1. Channelrhodopsin-1, Retinal and Its Analogs
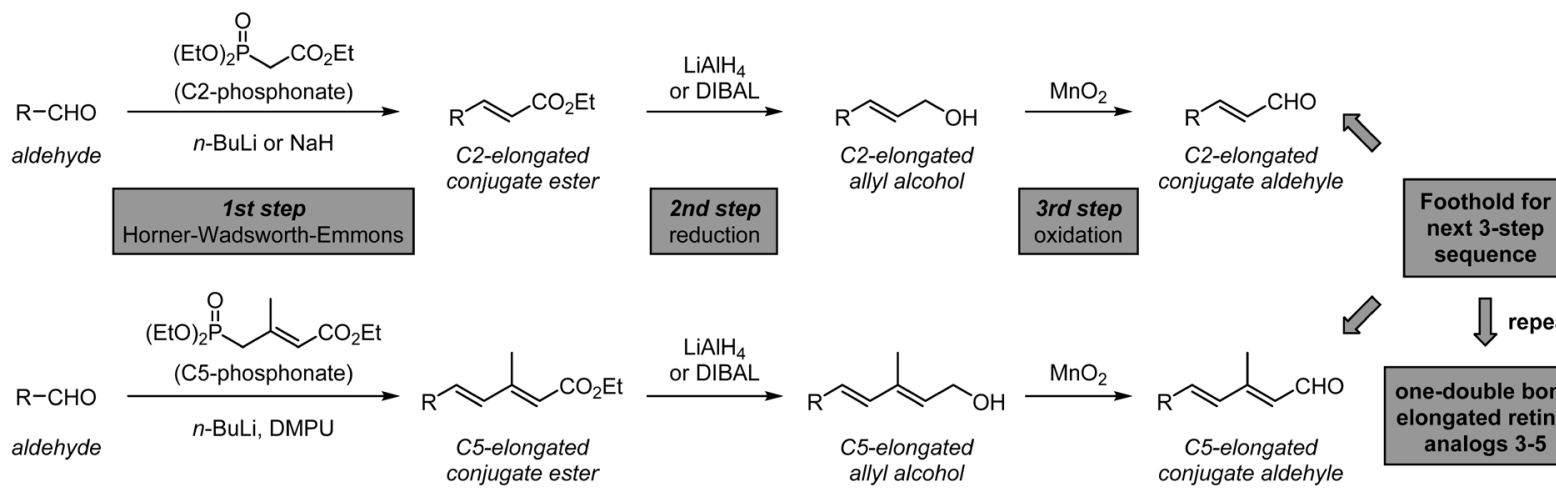

-cyclocitral (6a) by a C2-/C5-/C5-elongated sequence (Chart 2). In the Horner-Wadsworth-Emmons reaction of $\mathrm{C} 2$ phosphonate, the $E$-isomer was obtained exclusively. On the contrary, in the case of C5-phoshonate, the newly produced conjugate ester was obtained as a stereoisomeric mixture with a terminal double bond $(E: Z=9: 1$ to $18: 1)$, and it is well known that $N, N$-dimethylpropyleneurea (DMPU) plays an important role for this high stereoselectivity. ${ }^{22)}$ As the separation of stereoisomers was difficult, the stereoisomeric mixture was used for the next reaction, and the all- $E$ isomer was easily isolated after conversion to the aldehyde by column chromatography. In a similar fashion, A2-6ex (3b) was prepared from safranal (6b).

A1-10ex (4a) and A2-10ex (4b) were prepared from $\beta$-ionylideneacetaldehyde $(\mathbf{9 a})^{23)}$ and 3,4-didehydro- $\beta$ ionylideneacetaldehyde $(\mathbf{9 b})^{24)}$ by $\mathrm{C} 2-/ \mathrm{C} 5$-elongated sequence (Chart 3).

Chart 1. Three-Step Sequence for Conjugate Aldehyde Construction
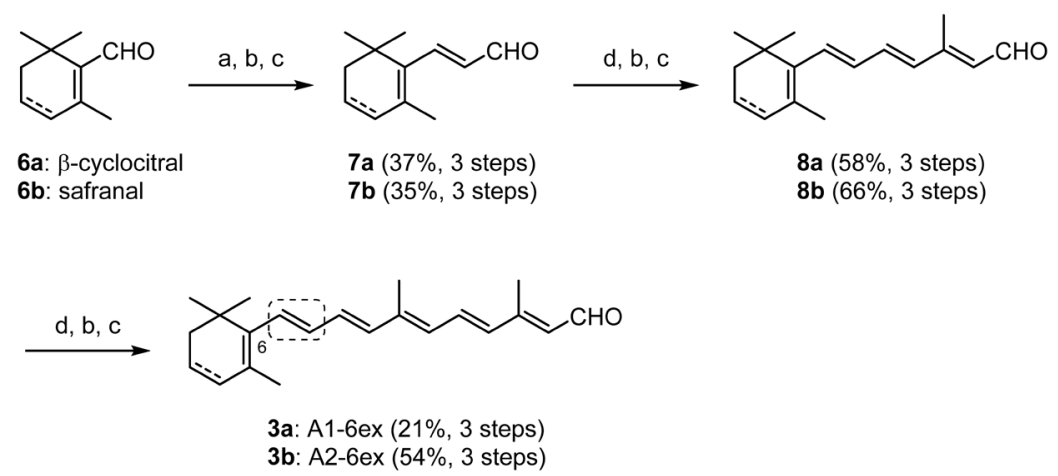

Reagents and conditions: (a) triethyl phosphonoacetate, $n$-BuLi or $\mathrm{NaH}, \mathrm{THF}, 0^{\circ} \mathrm{C}$; (b) $\mathrm{LiAlH}_{4}, \mathrm{Et}_{2} \mathrm{O}, 0^{\circ} \mathrm{C}$ (for $\mathbf{6 a}, 7 \mathbf{a}, \mathbf{8 a}$ ) or DIBAL, THF, $-78^{\circ} \mathrm{C}$ (for $\mathbf{6 b}, 7 \mathbf{b}, \mathbf{8 b}$ ); (c) $\mathrm{MnO}_{2}, \mathrm{Et}_{2} \mathrm{O}$, room temperature (r.t.); (d) triethyl 3-methyl-4-phosphonocrotonate, $n$-BuLi, DMPU, THF, $-78^{\circ} \mathrm{C}$ to r.t.

Chart 2. Synthesis of A1-6ex (3a) and A2-6ex (3b) 


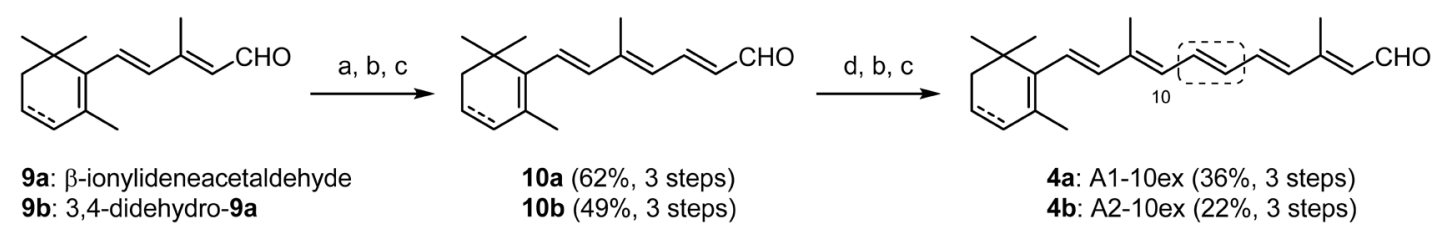

Reagents and conditions: (a) triethyl phosphonoacetate, $\mathrm{NaN}(\mathrm{TMS})_{2}$ or $\mathrm{NaH}, \mathrm{THF}, 0^{\circ} \mathrm{C}$; (b) $\mathrm{LiAlH}_{4}, \mathrm{Et}_{2} \mathrm{O}, 0^{\circ} \mathrm{C}$ (for $\left.9 \mathbf{a}, \mathbf{1 0 a}\right)$ or $\mathrm{DIBAL}, \mathrm{THF},-78^{\circ} \mathrm{C}$ (for $9 \mathbf{b}, \mathbf{1 0 b}$ ); (c) $\mathrm{MnO}_{2}, \mathrm{Et}_{2} \mathrm{O}$, r.t.; (d) triethyl 3-methyl-4-phosphonocrotonate, $n$-BuLi, DMPU, THF, $-78^{\circ} \mathrm{C}$ to r.t.

Chart 3. Synthesis of A1-10ex (4a) and A2-10ex (4b)

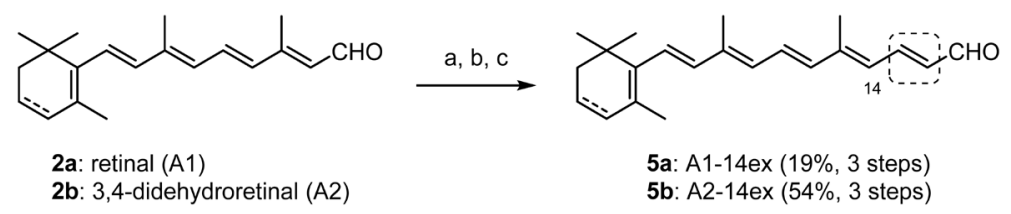

Reagents and conditions: (a) triethyl phosphonoacetate, $\mathrm{NaN}(\mathrm{TMS})_{2}$ or $\mathrm{NaH}, \mathrm{THF}, 0^{\circ} \mathrm{C}$; (b) $\mathrm{LiAlH}_{4}, \mathrm{Et}_{2} \mathrm{O}, 0^{\circ} \mathrm{C}$ (for $\mathbf{2 a}$ ) or $\mathrm{DIBAL}, \mathrm{THF}-78^{\circ} \mathrm{C}$ (for $\mathbf{2 b}$ ); (c) $\mathrm{MnO}_{2}, \mathrm{Et}_{2} \mathrm{O}$, r.t.

Chart 4. Synthesis of A1-14ex (5a) and A2-14ex (5b)

Although A1-14ex (5a) was a known compound as $14^{\prime}$-apo- $\beta$-carotenal, which was produced by the oxidative degradation of $\beta, \beta$-carotene, ${ }^{21)}$ we prepared $\mathbf{5 a}$ by the $\mathrm{C} 2$ elongated sequence from retinal (2a). ${ }^{25)}$ In a similar fashion, A2-14ex (5b) was prepared in 54\% overall yield from 3,4-didehydroretinal (2b) ${ }^{24)}$ (Chart 4).

\section{Binding Experiment with Opsins}

With the new chromophores in hand, we next examined their binding efficiency with opsins of ReaChR and ChrimsonR. All analogs bound to both opsins to form new ChRs. The spectra from ReaChR and ChrimsonR are shown in Fig. 2 and 3, respectively, where the absorption spectra were normalized to absorbance 1.0 at $278 \mathrm{~nm}$. These data were summarized in Tables 1, 2.

Among the ReaChR analogs, the A2-ReaChR formed from $\mathbf{2 b}$, having an extra double bond in the cyclohexene ring compared to retinal, showed $\lambda_{\max }$ at $580 \mathrm{~nm}$ with a $42 \mathrm{~nm}$ red-shift compared to the A1-ReaChR (native ReaChR, $\lambda_{\text {max }}$ at $538 \mathrm{~nm}$ ). In using A1 analogs having the same conjugated system of A2, the absorption maxima of three new ChRs (A1-6ex-ReaChR [570 nm], A1-10ex-ReaChR [569nm] and A1-14ex-ReaChR [546 nm]) were shorter than that of A2ReaChR. When A2-analogs, possessing a $\pi$-electron system elongated by one more double bond than A2, were used as chromophore, the different results were obtained according to the chromophore. Thus, the A2-14ex-ReaChR showed $\lambda_{\max }$ at $579 \mathrm{~nm}$, which was almost the same as A2-ReaChR, whereas A2-6ex-ReaChR and A2-10ex-ReaChR exhibited $\lambda_{\max }$ at $607 \mathrm{~nm}$ and $596 \mathrm{~nm}$, respectively, which are longer than that of A2-ReaChR and their red-shift values were $69 \mathrm{~nm}$ and $58 \mathrm{~nm}$ relative to the Al-ReaChR.

In addition, the shape of absorption spectra broadened the band width. As a result, the long-wavelength spectral boundary $^{13)}$ of A2-6ex-ReaChR and A2-10ex-ReaChR were extended to $672 \mathrm{~nm}$ (shift of $84 \mathrm{~nm}$ ) and $673 \mathrm{~nm}$ (shift of $85 \mathrm{~nm}$ ), respectively. These red-shift values were greater than that of A2-14ex-ReaChR $(68 \mathrm{~nm})$. It is noteworthy that the position of inserted one double bond was very important in causing the effective red-shift in the absorption spectra.

Similar tendencies were also observed in ChrimsonR ana- logs. In the case of $\mathrm{A} 1$ analogs having the same conjugated system of A2, absorption maxima of all new ChRs (A1-6exChrimsonR [625 nm] and A1-10ex-ChrimsonR [636 nm], A1-14ex-ChrimsonR [597 nm]) were the same or of shorter wavelengths than that of A2-ChrimsonR $(636 \mathrm{~nm})$. When A2 analogs were used as the chromophore, the $\lambda_{\max }$ of A2-14exChrimsonR $(634 \mathrm{~nm})$ was shorter than that of A2-ChrimsonR; on the other side, the $\lambda_{\max }$ of A2-6ex-ChrimsonR $(651 \mathrm{~nm})$ and A2-10ex-ChrimsonR $(654 \mathrm{~nm})$ were slightly red-shifted (15 and $18 \mathrm{~nm}$ ) compared to that of A2-ChrimsonR. The redshift values relative to A1-ChrimsonR (native ChrimsonR, $587 \mathrm{~nm}$ ) were moved 64 and $67 \mathrm{~nm}$, respectively. Furthermore, the width expansion of the absorption spectra in A2-6exChrimsonR and A2-10ex-ChrimsonR were more remarkable than for A2-14ex-ChrimsonR, with the long-wavelength spectral boundaries being extended to $746 \mathrm{~nm}$ (shift of $102 \mathrm{~nm}$ ) and $756 \mathrm{~nm}$ (shift of $112 \mathrm{~nm}$ ), respectively. In both cases, these positions were over $700 \mathrm{~nm}$ and reached into the far-red region (710-850 nm).

The capability of a new ChR to absorb the visible light was estimated by the value of relative absorbance $\left(\mathrm{Abs}_{\max } /\right.$ $\left.\mathrm{Abs}_{278 \mathrm{~nm}}\right)$. While the relative absorbance depends on the binding efficiency of the analogs, it would be affected by the difference in the extinction coefficients and/or stability of formed pigments. ${ }^{18)}$ All analogs seemed to bind with opsin smoothly to afford new ReaChRs (Table 1). In contrast, in the case of ChrimsonR, a remarkable difference was observed. Thus, A2 and its analogs gave values similar to retinal, whereas the value of A1 analogs were significantly decreased (Table 2). These results suggested that the binding pocket in ChrimsonR was not suitable for the A1 analogs due to their steric hindrance. Such steric hindrances might be reduced in the case of A2 analogs by the introduction of a double bond into the cyclohexene ring. To clarify these observations, the interactions between chromophore and amino acid residues of opsin are now in progress using computational docking simulations.

\section{Conclusion}

We designed and prepared six new kinds of chromophores, with one double bond inserted into the polyene side chain of retinal (A1) or 3,4-didehydroretinal (A2) for producing the 


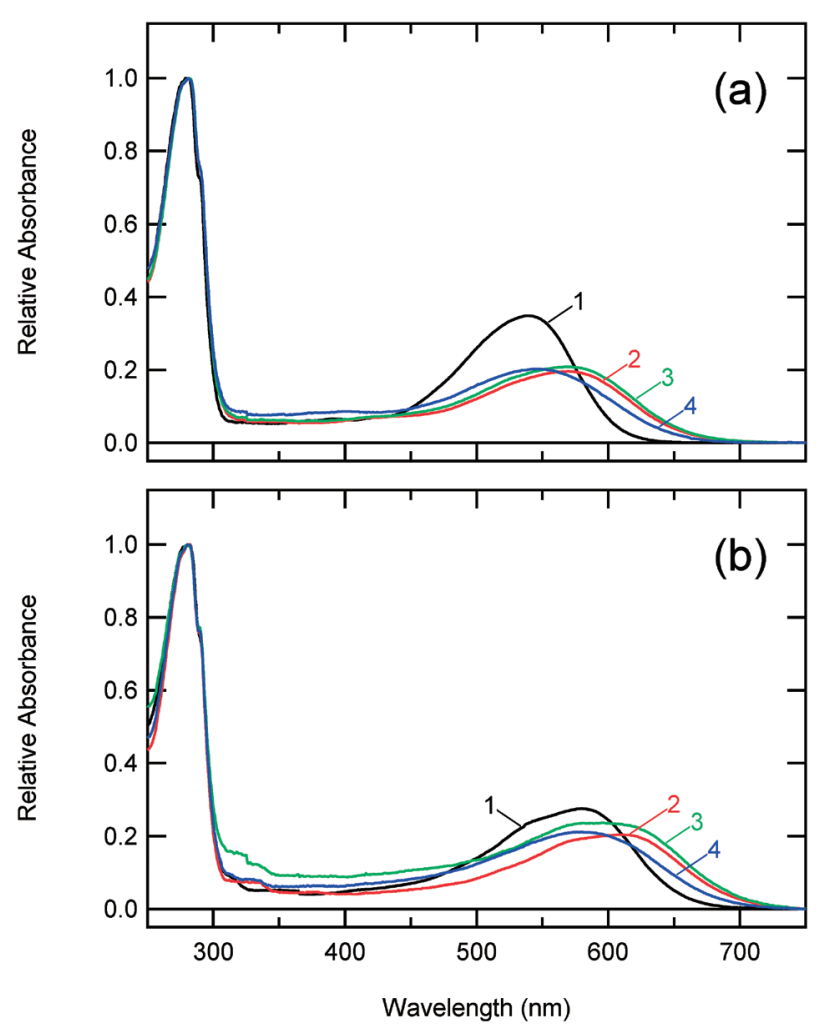

Fig. 2. UV-Vis Absorption Spectra of ReaChRs

Bearing (A) A1 or its analogs and (B) A2 or its analogs. With $\mathrm{A} 1$ or $\mathrm{A} 2$ (black, 1), 6ex (red, 2), 10ex (green, 3) and 14ex (blue, 4). The contribution of ReaChR regenerated by the endogenous A1 in HEK 293 cells was subtracted. All the absorption spectra were normalized to 1.0 at $278 \mathrm{~nm}$.

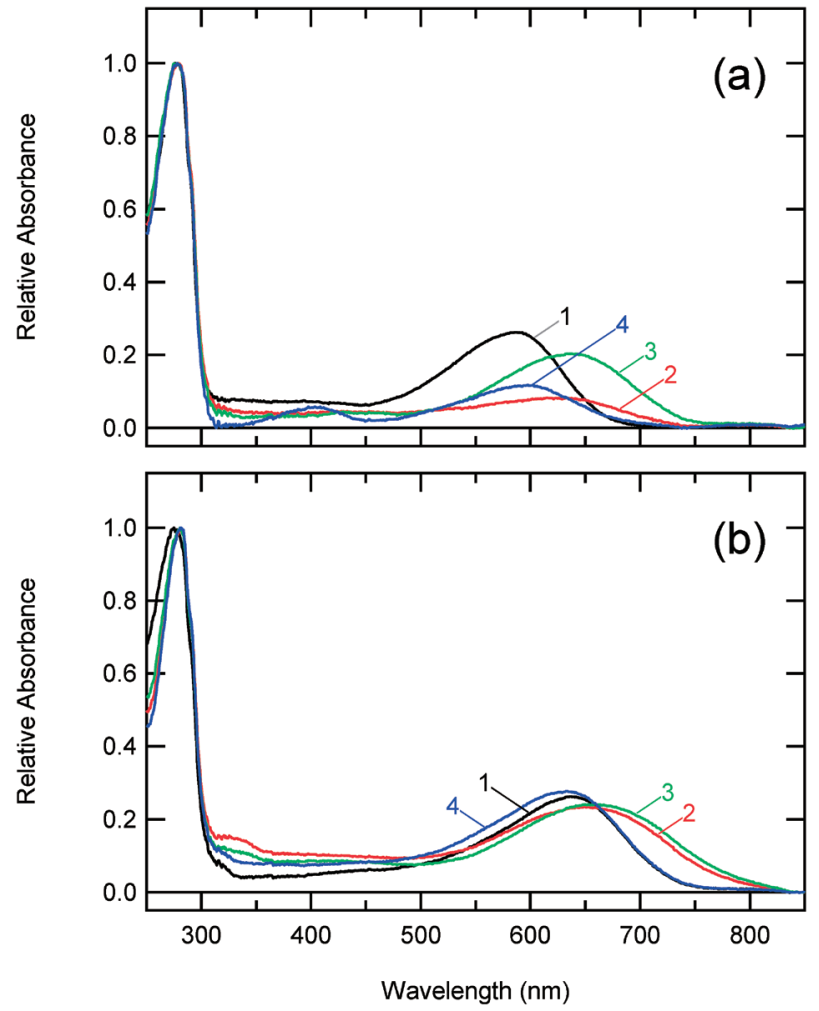

Fig. 3. UV-Vis Absorption Spectra of ChrimsonRs

Bearing (A) $\mathrm{A} 1$ or its analogs and (B) A2 or its analogs. With $\mathrm{A} 1$ or $\mathrm{A} 2$ (black, 1), 6ex (red, 2), 10ex (green, 3) and 14ex (blue, 4). The contribution of ChrimsonR regenerated by the endogenous A1 in HEK 293 cells was subtracted. All the absorption spectra were normalized to 1.0 at $278 \mathrm{~nm}$.

Table 1. Absorption Characteristics of ReaChR Aanalogs

\begin{tabular}{|c|c|c|c|c|c|c|c|c|}
\hline & \multicolumn{4}{|c|}{ A1-Analog } & \multicolumn{4}{|c|}{ A2-Analog } \\
\hline & A1 & $6 \mathrm{ex}$ & $10 \mathrm{ex}$ & $14 \mathrm{ex}$ & A2 & $6 e x$ & $10 \mathrm{ex}$ & $14 \mathrm{ex}$ \\
\hline$\lambda_{\max }(\mathrm{nm})$ & 538 & 570 & 569 & 546 & 580 & 607 & 596 & 579 \\
\hline Shift $(\Delta \mathrm{nm})^{a)}$ & - & 32 & 31 & 8 & 42 & 69 & 58 & 41 \\
\hline $1 / \mathrm{e} \lambda_{\max }(\mathrm{nm})$ & 588 & 632 & 635 & 620 & 634 & 672 & 673 & 656 \\
\hline Shift $(\Delta \mathrm{nm})^{a)}$ & - & 44 & 47 & 32 & 46 & 84 & 85 & 68 \\
\hline Relative absorbance ${ }^{b)}$ & 0.35 & 0.20 & 0.21 & 0.20 & 0.28 & 0.20 & 0.24 & 0.21 \\
\hline
\end{tabular}

a) Shift from A1-ReaChR. $b$ ) The values of $\mathrm{Abs}_{\max } / \mathrm{Abs}_{278 \mathrm{~nm}}$.

Table 2. Absorption Characteristics of ChrimsonR Analogs

\begin{tabular}{|c|c|c|c|c|c|c|c|c|}
\hline & \multicolumn{4}{|c|}{ A1-Analog } & \multicolumn{4}{|c|}{ A2-Analog } \\
\hline & A1 & $6 \mathrm{ex}$ & $10 \mathrm{ex}$ & $14 \mathrm{ex}$ & $\mathrm{A} 2$ & $6 \mathrm{ex}$ & $10 \mathrm{ex}$ & $14 \mathrm{ex}$ \\
\hline$\lambda_{\max }(\mathrm{nm})$ & 587 & 625 & 636 & 597 & 636 & 651 & 654 & 634 \\
\hline Shift $(\Delta \mathrm{nm})^{a)}$ & - & 38 & 49 & 10 & 49 & 64 & 67 & 47 \\
\hline $1 / \mathrm{e} \lambda_{\max }(\mathrm{nm})$ & 644 & 700 & 711 & 660 & 703 & 746 & 756 & 702 \\
\hline $\operatorname{Shift}(\Delta \mathrm{nm})^{a)}$ & - & 56 & 67 & 16 & 59 & 102 & 112 & 58 \\
\hline Relative absorbance ${ }^{b)}$ & 0.26 & 0.08 & 0.20 & 0.12 & 0.26 & 0.23 & 0.24 & 0.28 \\
\hline
\end{tabular}

a) Shift from A1-ChrimsonR. b) The values of $\mathrm{Abs}_{\max } / \mathrm{Abs}_{278 \mathrm{~nm}}$.

red-shifted ChRs. All chromophores bound with ReaChR and ChrimsonR to afford the new red-shifted ChRs. Furthermore, the absorption spectra of all new ChRs were broadened towards the long-wavelength side and remarkable red-shifts were observed. Among the new ChRs, A2-10ex-ChrimsonR exhibited the longest red-shift effect in its absorption spectrum. Therefore, A2-10ex chromophore seemed to be the most promising for further development of a new red-shifted ChR. Photochemical behaviors of these new ChRs are in progress and will be published elsewhere.

\section{Experimental}

UV-vis spectra were recorded on a JASCO Ubest-55 or JASCO V-650 instrument. IR spectra were measured on a 
PerkinElmer, Inc. FT-IR spectrometer, model Paragon 1000 or Horiba FT-IR spectrometer, model FT-720. NMR spectra were obtained on a Varian Mercury-300, a VXR-500 or a Brucker Avance III 600 superconducting FT-NMR spectrometer. Chemical shifts $(\delta)$ are reported in ppm relative to tetramethylsilane as an internal reference $\left(\mathrm{CDCl}_{3}: \delta=0 \mathrm{ppm}\right.$ for $\left.{ }^{1} \mathrm{H}\right)$ or residual solvent signals $\left(\mathrm{CDCl}_{3}: \delta=77 \mathrm{ppm}\right.$ for $\left.{ }^{13} \mathrm{C}\right)$. Mass spectra were taken on a Thermo Fisher Scientific Exactive spectrometer. Column chromatography was performed using Kanto Silica Gel $60 \mathrm{~N}$ (spherical, neutral). All reagents were used as obtained commercially unless otherwise noted.

General Procedure for the Synthesis of C2-Elongeted Conjugate Ester by Horner-Wadsworth-Emmons Reaction (GP1) To a stirred solution of triethyl phosphonoacetate (C2phosphonate, 2.5-5.0 eq.) in dry tetrahydrofuran (THF) $(0.2 \mathrm{M} /$ phosphonate) was added a solution of $\mathrm{NaN}(\mathrm{TMS})_{2}$ (2.5-5.0 eq.) or $n$-BuLi (2.5-5.0 eq.) at $0^{\circ} \mathrm{C}$, and the mixture was stirred at the same temperature for $15 \mathrm{~min}$. To this mixture a solution of aldehyde (1 eq.) in THF (1 M/aldehyde) was added, and the reaction mixture was stirred at room temperature (r.t.) until the reaction was completed. The reaction was quenched with a saturated aqueous solution of $\mathrm{NH}_{4} \mathrm{Cl}$, and then extracted with ethyl acetate. The combined extracts were washed with brine, dried over $\mathrm{Na}_{2} \mathrm{SO}_{4}$, and concentrated in vacuo. The residue was purified by flash chromatography on silica gel to afford the one double bond elongated conjugate ester. In the case of A2 analogs, sodium hydride $(\mathrm{NaH})(1.5$ eq., $60 \%$ suspension in mineral oil) was used as a base instead of $\mathrm{NaN}(\mathrm{TMS})_{2}$.

General Procedure for the Synthesis of C5-Elongeted Conjugate Ester by Horner-Wadsworth-Emmons Reaction (GP2) To a stirred solution of triethyl 3-methyl-4-phosphonocrotonate (C5-phosphonate, 3.0 eq.) and DMPU (4 eq.) in dry THF (0.2 M/aldehyde), $n$-BuLi (3.0 eq.) was added at $0{ }^{\circ} \mathrm{C}$. The resulting mixture was stirred at the same temperature for $20 \mathrm{~min}$ and then cooled to $-78^{\circ} \mathrm{C}$. To this mixture a solution of aldehyde (1 eq.) in THF ( $1 \mathrm{M} /$ aldehyde) was slowly added, and the reaction mixture was allowed to come to r.t. and then stirred for overnight. The reaction was quenched with a saturated aqueous solution of $\mathrm{NH}_{4} \mathrm{Cl}$, and then extracted with ethyl acetate. The combined extracts were washed with brine, dried over $\mathrm{Na}_{2} \mathrm{SO}_{4}$, and concentrated in vacuo. The residue was purified by flash chromatography on silica gel to afford the two double bonds elongated conjugate ester as a stereoisomeric mixture $(E: Z=9: 1$ to $18: 1)$. The mixture was used for the next reaction without further separation of stereoisomers.

General Procedure for the Conversion from Ester to Aldehyde (GP3) In the case of A1-analogs, to a stirred suspension of $\mathrm{LiAlH}_{4}$ (2.0 eq.) in dry $\mathrm{Et}_{2} \mathrm{O}(0.2 \mathrm{M} /$ aldehyde) was added a solution of ester (1 eq.) in $\mathrm{Et}_{2} \mathrm{O}(0.2 \mathrm{M} / \mathrm{ester})$ at $0^{\circ} \mathrm{C}$, and the resulting mixture was stirred at the same temperature for $1 \mathrm{~h}$. To this mixture aqueous silica gel $\left(\mathrm{H}_{2} \mathrm{O} / \mathrm{SiO}_{2}=1: 5\right)$ was added and the resulting mixture was stirred at r.t. for $1 \mathrm{~h}$. The reaction mixture was filtered through Celite with $\mathrm{Et}_{2} \mathrm{O}$, dried over $\mathrm{Na}_{2} \mathrm{SO}_{4}$, and concentrated in vacuo. The resultant allyl alcohol was used for the next $\mathrm{MnO}_{2}$ oxidation step without further purification.

In the case of A2-analogs, to a solution of ester (1 eq.) in THF (0.1 M/ester) was added DIBAL (3.5 eq., $1.0 \mathrm{M}$ in hexane) dropwise at $-78^{\circ} \mathrm{C}$, and the mixture was stirred at the same temperature for $2 \mathrm{~h}$. The mixture was quenched with $\mathrm{H}_{2} \mathrm{O}$ / $\mathrm{SiO}_{2}$, and was stirred at r.t. for $30 \mathrm{~min}$. The resulting mix- ture was filtered through Celite with $\mathrm{Et}_{2} \mathrm{O}$, and evaporated in vacuo. The resultant allyl alcohol was used for the next $\mathrm{MnO}_{2}$ oxidation step without further purification.

To a solution of ally alcohol in $\mathrm{Et}_{2} \mathrm{O}(0.04 \mathrm{M})$ was added $\mathrm{MnO}_{2}$ (10 times weight relative to ester) at r.t. and was stirred for $14-18 \mathrm{~h}$. The resulting mixture was filtered through Celite with $\mathrm{Et}_{2} \mathrm{O}$, and concentrated in vacuo. The residue was purified by flash column chromatography on silica gel to afford the aldehyde as pure $E$ stereoisomer.

(E)-3-(2,6,6-Trimethylcyclohexen-1-yl)-2-propen-1-al (7a) According to GP1, ethyl (E)-3-(2,6,6-trimethylcyclohexen-1-yl)-2-propenate $(1.37 \mathrm{~g}, 94 \%)$ was obtained from $\beta$-cyclocitral (6a: $1.00 \mathrm{~g}, 6.57 \mathrm{mmol})$, triethyl phosphonoacetate $(7.36 \mathrm{~g}, 32.9 \mathrm{mmol})$ and $n$-BuLi $(20.5 \mathrm{~mL}, 1.57 \mathrm{M}$ in hexane, $32.2 \mathrm{mmol})$. Eluent: hexane $/ \mathrm{EtOAc}=9: 1$. According to GP3, 7a (428 mg, 37\%, in 3 steps from 6a) was obtained from ethyl (E)-3-(2,6,6-trimethylcyclohexen-1-yl)-2-propenoate $\quad(1.37 \mathrm{~g}$, $6.18 \mathrm{mmol}), \mathrm{LiAlH}_{4}(469 \mathrm{mg}, 12.4 \mathrm{mmol})$ and $\mathrm{MnO}_{2}(85 \% \mathrm{pu}-$ rity, $14.0 \mathrm{~g}, 137 \mathrm{mmol})$. Eluent: hexane $/ \mathrm{Et}_{2} \mathrm{O}=4: 1$. Spectral data were identical with those of the literature. ${ }^{26)}$

7a: Pale yellow oil. IR $\left(\mathrm{CHCl}_{3}\right) v_{\max } \mathrm{cm}^{-1}: 2928,1676,1605$. ${ }^{1} \mathrm{H}-\mathrm{NMR}\left(300 \mathrm{MHz}, \mathrm{CDCl}_{3}\right) \delta: 9.51(1 \mathrm{H}, \mathrm{d}, J=7.8 \mathrm{~Hz}), 7.26$ $(1 \mathrm{H}, \mathrm{d}, J=16.2 \mathrm{~Hz}), 6.17(1 \mathrm{H}, \mathrm{dd}, J=16.2,7.8 \mathrm{~Hz}), 2.10(2 \mathrm{H}$, t, $J=6.0 \mathrm{~Hz}), 1.79(3 \mathrm{H}, \mathrm{s}), 1.70-1.53(2 \mathrm{H}, \mathrm{m}), 1.53-1.47(2 \mathrm{H}$, m), $1.09(6 \mathrm{H}, \mathrm{s}) .{ }^{13} \mathrm{C}-\mathrm{NMR}\left(75 \mathrm{MHz}, \mathrm{CDCl}_{3}\right) \delta: 194.95,152.99$, 139.80, 136.25, 132.79, 40.17, 34.26, 34.24, 28.90, 22.02, 18.94.

(E)-3-(2,6,6-Trimethylcyclohexa-1,3-dien-1-yl)-2-propen1-al (7b) According to GP1, ethyl $(E)-3-(2,6,6$-trimethylcyclohexa-1,3-dien-1-yl)-2-propenate $(11.9 \mathrm{~g}, 87 \%)$ was obtained from safranal $(\mathbf{6 b}: 9.33 \mathrm{~mL}, 60.0 \mathrm{mmol})$, triethyl phosphonoacetate $(20.2 \mathrm{~g}, 90.0 \mathrm{mmol})$ and $\mathrm{NaH}(60 \%, 3.60 \mathrm{~g}, 90.0 \mathrm{mmol})$. Eluent: hexane $/ \mathrm{Et}_{2} \mathrm{O}=20: 1$. According to $\mathbf{G P 3}, 7 \mathbf{b}(3.74 \mathrm{~g}$, $35 \%$, in 3 steps from $6 \mathbf{b})$ was obtained from ethyl $(E)$ 3-(2,6,6-trimethylcyclohexa-1,3-dien-1-yl)-2-propenate (11.9g, $53.8 \mathrm{mmol}), \mathrm{LiAlH}_{4}(5.11 \mathrm{~g}, 135 \mathrm{mmol})$ and $\mathrm{MnO}_{2}(85 \%$ purity, $119 \mathrm{~g}, 1.16 \mathrm{~mol})$. Eluent: hexane $/ \mathrm{Et}_{2} \mathrm{O}=10: 1$

7b: Yellow solid. IR $\left(\mathrm{CHCl}_{3}\right) v_{\max } \mathrm{cm}^{-1}: 2962,1670,1607$. ${ }^{1} \mathrm{H}-\mathrm{NMR}\left(300 \mathrm{MHz}, \mathrm{CDCl}_{3}\right) \delta: 9.54(1 \mathrm{H}, \mathrm{d}, J=7.8 \mathrm{~Hz}), 7.26$ $(1 \mathrm{H}, \mathrm{d}, J=16.2 \mathrm{~Hz}), 6.26(1 \mathrm{H}, \mathrm{dd}, J=16.2,7.8 \mathrm{~Hz}), 5.99-5.89$ $(2 \mathrm{H}, \mathrm{m}), 2.15(2 \mathrm{H}, \mathrm{d}, J=3.3 \mathrm{~Hz}), 1.94(3 \mathrm{H}, \mathrm{s}), 1.11(6 \mathrm{H}, \mathrm{s})$. ${ }^{13} \mathrm{C}-\mathrm{NMR}\left(75 \mathrm{MHz}, \mathrm{CDCl}_{3}\right) \delta: 194.35,151.23,135.69,135.09$, 131.62, 129.68, 129.64, 40.16, 34.01, 26.53, 20.41. High resolution electrospray ionization (HR-ESI) MS Calcd for $\mathrm{C}_{12} \mathrm{H}_{17} \mathrm{O}[\mathrm{M}+\mathrm{H}]^{+}:$177.1274. Found: 177.1273.

(2E,4E,6E)-3-Methyl-7-(2,6,6-trimethylcyclohexen-1-yl)2,4,6-heptatrien-1-al (8a) According to GP2, ethyl (E)3-methyl-7-(2,6,6-trimethylcyclohexen-1-yl)-2,4,6-heptatrienoate $(628 \mathrm{mg}, 90 \%)$ was obtained from $7 \mathbf{a}(428 \mathrm{mg}, 2.40 \mathrm{mmol})$, triethyl 3-methyl-4-phosphonocrotonate $(1.77 \mathrm{~g}, 7.20 \mathrm{mmol})$, $n$-BuLi $(4.50 \mathrm{~mL}, 1.57 \mathrm{M}$ in hexane, $7.07 \mathrm{mmol})$ and DMPU $(1.10 \mathrm{~mL}, \quad 9.59 \mathrm{mmol})$. Eluent: hexane $/$ EtOAc $=9: 1$. According to GP3, 8a (360 mg, 58\%, in 3 steps from 7a) was obtained from ethyl (2E,4E,6E)-3-methyl-7-(2,6,6-trimethylcyclohexen-1-yl)-2,4,6-heptatrienoate $(628 \mathrm{mg}, 2.18 \mathrm{mmol})$, $\mathrm{LiAlH}_{4}(165 \mathrm{mg}, 4.35 \mathrm{mmol})$ and $\mathrm{MnO}_{2}$ (85\% purity, $6.30 \mathrm{~g}$, $61.6 \mathrm{mmol}$ ). Eluent: hexane $/ \mathrm{Et}_{2} \mathrm{O}=4: 1$. This compound is known and main signals of ${ }^{1} \mathrm{H}-\mathrm{NMR}$ were reported in the literature. $^{27)}$

8a: Pale yellow oil. IR $\left(\mathrm{CHCl}_{3}\right) v_{\max } \mathrm{cm}^{-1}: 2932,1656,1594$. ${ }^{1} \mathrm{H}-\mathrm{NMR}\left(300 \mathrm{MHz}, \mathrm{CDCl}_{3}\right) \delta: 10.10(1 \mathrm{H}, \mathrm{d}, J=8.1 \mathrm{~Hz}), 6.82$ $(1 \mathrm{H}, \mathrm{dd}, J=15.6,10.5 \mathrm{~Hz}), 6.46(1 \mathrm{H}, \mathrm{d}, J=15.6 \mathrm{~Hz}), 6.31(1 \mathrm{H}$, 
d, $J=15.6 \mathrm{~Hz}), 6.26(1 \mathrm{H}, \mathrm{dd}, J=15.6,10.5 \mathrm{~Hz}), 5.95(1 \mathrm{H}, \mathrm{d}$, $J=8.1 \mathrm{~Hz}), 2.31(3 \mathrm{H}, \mathrm{s}), 2.05(2 \mathrm{H}, \mathrm{t}, J=6.3 \mathrm{~Hz}), 1.75(3 \mathrm{H}, \mathrm{s})$, 1.64-1.56 (2H, m), 1.52-1.44 (2H, m), $1.05(6 \mathrm{H}, \mathrm{s}) .{ }^{13} \mathrm{C}-\mathrm{NMR}$ $\left(75 \mathrm{MHz}, \mathrm{CDCl}_{3}\right) \delta: 191.16,154.91,137.53,137.25,133.17$, $132.56,132.40,128.95,39.71,34.15,33.39,28.90,21.79,19.05$, 13.00 .

(2E,4E,6E)-3-Methyl-7-(2,6,6-trimethylcyclohexa-1,3dien-1-yl)-2,4,6-heptatrien-1-al (8b) According to GP2, ethyl (2E,4E,6E)-3-methyl-7-(2,6,6-trimethylcyclohexa-1,3dien-1-yl)-2,4,6-heptatrienoate $(7.98 \mathrm{~g}, 95 \%)$ was obtained from $7 \mathbf{b}(5.20 \mathrm{~g}, 29.5 \mathrm{mmol})$, triethyl 3-methyl-4- phosphonocrotonate $(11.6 \mathrm{~g}, 44.2 \mathrm{mmol}), n$-BuLi $(28.0 \mathrm{~mL}, 1.58 \mathrm{M}$ in hexane, $44.2 \mathrm{mmol})$ and DMPU $(7.11 \mathrm{~mL}, 59.0 \mathrm{mmol})$. Eluent: hexane/EtOAc $=30: 1$.

According to GP3, 8b $(4.72 \mathrm{~g}, 66 \%$, in 3 steps from $7 \mathbf{b})$ was obtained from ethyl $(2 E, 4 E, 6 E)-3$-methyl-7-(2,6,6-trimethylcyclohexa-1,3-dien-1-yl)-2,4,6-heptatrienoate (7.98 g, 27.9 mmol), DIBAL $(100 \mathrm{~mL}, 1.0 \mathrm{M}$ in hexane, $100 \mathrm{mmol})$ and $\mathrm{MnO}_{2}(85 \%$ purity, $79.8 \mathrm{~g}, 780 \mathrm{mmol})$. Eluent: hexane $/ \mathrm{Et}_{2} \mathrm{O}=4: 1$.

8b: Yellow solid. IR $\left(\mathrm{CHCl}_{3}\right) v_{\max } \mathrm{cm}^{-1}:$ 3013, 1651, 1592. ${ }^{1} \mathrm{H}-\mathrm{NMR}\left(300 \mathrm{MHz}, \mathrm{CDCl}_{3}\right) \delta: 10.11(1 \mathrm{H}, \mathrm{d}, J=8.1 \mathrm{~Hz}), 6.83$ $(1 \mathrm{H}, \mathrm{dd}, J=15.6,9.9 \mathrm{~Hz}), 6.48(1 \mathrm{H}, \mathrm{d}, J=15.6 \mathrm{~Hz}), 6.36(1 \mathrm{H}$, dd, $J=15.6,9.9 \mathrm{~Hz}), 6.35(1 \mathrm{H}, \mathrm{d}, J=15.6 \mathrm{~Hz}), 5.96(1 \mathrm{H}, \mathrm{d}$, $J=8.1 \mathrm{~Hz}), 5.87(1 \mathrm{H}, \mathrm{d}, J=9.6 \mathrm{~Hz}), 5.79(1 \mathrm{H}, \mathrm{dt}, J=9.6$, $4.2 \mathrm{~Hz}), 2.31(\mathrm{~s}, 3 \mathrm{H}), 2.10(2 \mathrm{H}, \mathrm{dd}, J=4.2,0.9 \mathrm{~Hz}), 1.90(3 \mathrm{H}$, s), $1.06(6 \mathrm{H}, \mathrm{s}) .{ }^{13} \mathrm{C}-\mathrm{NMR}\left(75 \mathrm{MHz}, \mathrm{CDCl}_{3}\right) \delta: 191.00,154.66$, $137.48,137.42,135.86,133.45,131.81,129.84,129.51,128.96$, 126.43, 39.92, 33.86, 26.71, 20.39, 12.92. HR-ESIMS Calcd for $\mathrm{C}_{17} \mathrm{H}_{23} \mathrm{O}[\mathrm{M}+\mathrm{H}]^{+}:$243.1743. Found: 243.1745.

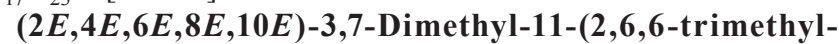
cyclohexen-1-yl)-2,4,6,8,10-undecapentaen-1-al (A1-6ex, 3a) According to GP2, ethyl $(2 E, 4 E, 6 E, 8 E, 10 E)-3,7-$ dimethyl-11-(2,6,6-trimethylcyclohexen-1-yl)-2,4,6,8,10-undecapentaenoate $(459 \mathrm{mg}, 93 \%)$ was obtained from 8a $(360 \mathrm{mg}, 1.39 \mathrm{mmol})$, triethyl 3-methyl-4-phosphonocrotonate $(1.02 \mathrm{~g}, 4.16 \mathrm{mmol}), n-\mathrm{BuLi}(2.60 \mathrm{~mL}, 1.57 \mathrm{M}$ in hexane, $4.08 \mathrm{mmol})$ and DMPU $(0.630 \mathrm{~mL}, 5.23 \mathrm{mmol})$. Eluent: hexane/ EtOAc $=9: 1$. According to GP3, 3a $(99.0 \mathrm{mg}, 21 \%$, in 3 steps from 8a) was obtained from ethyl $(2 E, 4 E, 6 E, 8 E, 10 E)-3,7-$ dimethyl-11-(2,6,6-trimethylcyclohexen-1-yl)-2,4,6,8,10-undecapentaenoate $(358 \mathrm{mg}, \quad 1.01 \mathrm{mmol}), \mathrm{LiAlH}_{4} \quad(77.0 \mathrm{mg}$, $2.02 \mathrm{mmol}$ ) and $\mathrm{MnO}_{2}(85 \%$ purity, $3.61 \mathrm{~g}, 35.3 \mathrm{mmol})$. Eluent: hexane $/ \mathrm{Et}_{2} \mathrm{O}=4: 1$.

3a: Orange solid. UV-vis (EtOH) $\lambda_{\max } 403 \mathrm{~nm}(\varepsilon=54300)$. nm. IR $\left(\mathrm{CHCl}_{3}\right) v_{\max } \mathrm{cm}^{-1}: 2931,1651,1602,1561 .{ }^{1} \mathrm{H}-\mathrm{NMR}$ $\left(300 \mathrm{MHz}, \mathrm{CDCl}_{3}\right) \delta: 10.10(1 \mathrm{H}, \mathrm{d}, J=8.4 \mathrm{~Hz}), 7.12(1 \mathrm{H}, \mathrm{dd}$, $J=15.0,11.4 \mathrm{~Hz}), 6.50(1 \mathrm{H}, \mathrm{dd}, J=15.0,9.9 \mathrm{~Hz}), 6.37(1 \mathrm{H}, \mathrm{d}$, $J=15.0 \mathrm{~Hz}), 6.29(2 \mathrm{H}, \mathrm{d}, J=15.0 \mathrm{~Hz}), 6.22(1 \mathrm{H}, \mathrm{d}, J=11.4 \mathrm{~Hz})$, $6.19(1 \mathrm{H}, \mathrm{dd}, J=15.3,9.9 \mathrm{~Hz}), 5.98(1 \mathrm{H}, \mathrm{d}, J=8.1 \mathrm{~Hz}), 2.33$ $(3 \mathrm{H}, \mathrm{s}), 2.03(2 \mathrm{H}, \mathrm{t}, J=6.0 \mathrm{~Hz}), 2.02(3 \mathrm{H}, \mathrm{s}), 1.74(3 \mathrm{H}, \mathrm{s})$, 1.64-1.58 (2H, m), 148-1.45 (2H, m), 1.04 (6H, s). ${ }^{13} \mathrm{C}-\mathrm{NMR}$ $\left(75 \mathrm{MHz}, \mathrm{CDCl}_{3}\right) \delta: 191.06,154.70,141.15,137.47,134.86$, $134.71,133.52,133.38,132.44,132.19,131.04,130.24,129.07$, 39.72, 34.17, 33.30, 28.92, 21.79, 19.15, 13.08. HR-ESIMS Calcd for $\mathrm{C}_{22} \mathrm{H}_{31} \mathrm{O}[\mathrm{M}+\mathrm{H}]^{+}:$311.2369. Found: 311.2368.

(2E, $4 E, 6 E, 8 E, 10 E)-3,7-D i m e t h y l-11-(2,6,6$ - tri methylcyclohexa-1,3-dien-1-yl)-2,4,6,8,10-undecapentaen-1-al (A2-6ex, 3b) According to GP2, ethyl (2E,4E,6E,8E,10E)-3,7-dimethyl-11-(2,6,6-trimethylcyclohexa-1,3-dien-1-yl)-2,4,6,8,10-undecapentaenoate $(2.99 \mathrm{~g}$, quant.) was obtained from $\mathbf{8 b}(1.94 \mathrm{~g}, 8.00 \mathrm{mmol})$, triethyl 3-methyl-4-phosphonocrotonate $(3.75 \mathrm{~g}, 12.0 \mathrm{mmol}), n$-BuLi $(7.59 \mathrm{~mL}, 1.58 \mathrm{M}$ in hexane, $12.0 \mathrm{mmol})$ and DMPU $(1.93 \mathrm{~mL}$, $16.0 \mathrm{mmol})$. Eluent: hexane $/ \mathrm{EtOAc}=30: 1$. According to GP3, 3b $(1.32 \mathrm{~g}, 54 \%$, in 3 steps from $8 \mathbf{b})$ was obtained from ethyl $\quad(2 E, 4 E, 6 E, 8 E, 10 E)$-3,7-dimethyl-11-(2,6,6-trimethylcyclohexa-1,3-dien-1-yl)-2,4,6,8,10-undecapentaenoate $(2.99 \mathrm{~g}$, $8.49 \mathrm{mmol})$, DIBAL $(29.7 \mathrm{~mL}, 1.0 \mathrm{M}$ in hexane, $29.7 \mathrm{mmol})$ and $\mathrm{MnO}_{2}$ (85\% purity, $\left.29.9 \mathrm{~g}, 292 \mathrm{mmol}\right)$. Eluent: hexane/ $\mathrm{Et}_{2} \mathrm{O}=5: 1$. Spectral data were shown in the literature. ${ }^{20)}$

$(2 E, 4 E, 6 E)-5$-Methyl-7-(2,6,6 -trimethylcyclohexen-1-yl)-2,4,6-heptatrien-1-al (10a) According to GP1, ethyl $\quad(2 E, 4 E, 6 E)-5$-methyl-7-(2,6,6-trimethylcyclohexen1-yl)-2,4,6- heptatrienoate $(1.20 \mathrm{~g}, 99 \%)$ was obtaind from $\beta$-ionylideneacetaldehyde ${ }^{23)}$ (9a: $916 \mathrm{mg}, 4.20 \mathrm{mmol}$ ), $\mathrm{NaN}(\mathrm{TMS})_{2} \quad(10.5 \mathrm{~mL}, 1.0 \mathrm{M}$ in THF, $10.5 \mathrm{mmol})$ and triethyl phosphonoacetate $(2.40 \mathrm{~g}, 10.5 \mathrm{mmol})$. Eluent: hexane/ $\mathrm{Et}_{2} \mathrm{O}=8: 1$. According to GP3, 10a $(586 \mathrm{mg}, 62 \%$, in 3 steps from 9a) was obtained from ethyl $(2 E, 4 E, 6 E)-5$-methyl7-(2,6,6-trimethylcyclohexen-1-yl)-2,4,6-heptatrienoate $(1.09 \mathrm{~g}$, $3.78 \mathrm{mmol}), \mathrm{LiAlH}_{4}(287 \mathrm{mg}, 7.57 \mathrm{mmol})$ and $\mathrm{MnO}_{2}(85 \%$ purity, $11.0 \mathrm{~g}, 107 \mathrm{mmol})$. Eluent: hexane $/ \mathrm{Et}_{2} \mathrm{O}=4: 1$. Spectra data were identical with those of the literature. ${ }^{26)}$

10a: Pale yellow oil. IR $\left(\mathrm{CHCl}_{3}\right) v_{\max } \mathrm{cm}^{-1}: 2932,1663$, 1590. ${ }^{1} \mathrm{H}-\mathrm{NMR}\left(300 \mathrm{MHz}, \mathrm{CDCl}_{3}\right) \delta: 9.61(1 \mathrm{H}, \mathrm{d}, J=8.1 \mathrm{~Hz})$, $7.53(1 \mathrm{H}, \mathrm{dd}, J=15.0,12.0 \mathrm{~Hz}), 6.50(1 \mathrm{H}, \mathrm{d}, J=15.9 \mathrm{~Hz}), 6.29$ $(1 \mathrm{H}, \mathrm{d}, J=12.0 \mathrm{~Hz}), 6.20(1 \mathrm{H}, \mathrm{d}, J=15.9 \mathrm{~Hz}), 6.15(1 \mathrm{H}, \mathrm{dd}$, $J=15.0,8.1 \mathrm{~Hz}), 2.09(3 \mathrm{H}, \mathrm{s}), 2.04(2 \mathrm{H}, \mathrm{t}, J=6.0 \mathrm{~Hz}), 1.72$ $(3 \mathrm{H}, \mathrm{s}), 1.69-1.58(2 \mathrm{H}, \mathrm{m}), 1.51-1.42(2 \mathrm{H}, \mathrm{m}), 1.04(6 \mathrm{H}, \mathrm{s})$. ${ }^{13} \mathrm{C}-\mathrm{NMR}\left(75 \mathrm{MHz}, \mathrm{CDCl}_{3}\right) \delta: 193.95,148.29,147.01,137.60$, $136.64,132.73,131.82,130.95,128.65,39.80,34.48,33.43$, 29.18, 22.01, 19.34, 13.37 .

(2E,4E,6E)-5-Methyl-7-(2,6,6-trimethylcyclohexa-1,3dien-1-yl)-2,4,6-heptatrien-1-al (10b) According to GP1, ethyl (2E,4E,6E)-5-methyl-7-(2,6,6-trimethylcyclohexa-1,3dien-1-yl)-2,4,6-heptatrienoate $(1.74 \mathrm{~g}, 79 \%)$ was obtained from 9b ${ }^{24)}(1.66 \mathrm{~g}, 7.69 \mathrm{mmol})$, triethyl phosphonoacetate $(2.59 \mathrm{~g}$, $11.5 \mathrm{mmol})$ and $\mathrm{NaH}(60 \%, 0.46 \mathrm{~g}, 11.5 \mathrm{mmol})$. Eluent: hexane $/ \mathrm{Et}_{2} \mathrm{O}=15: 1$. According to GP3, 10b $(0.914 \mathrm{~g}, 49 \%$, in 3 steps from 9b) was obtained from ethyl $(2 E, 4 E, 6 E)-5$-methyl7-(2,6,6-trimethylcyclohexa-1,3-dien-1-yl)-2,4,6-heptatrienoate $(1.74 \mathrm{~g}, 6.07 \mathrm{mmol})$, DIBAL $(21.2 \mathrm{~mL}, 1.0 \mathrm{M}$ in hexane, $21.2 \mathrm{mmol})$ and $\mathrm{MnO}_{2}(85 \%$ purity, $17.4 \mathrm{~g}, 170 \mathrm{mmol})$. Eluent: hexane/ $\mathrm{Et}_{2} \mathrm{O}=8: 1$.

10b: Yellow solid. IR $\left(\mathrm{CHCl}_{3}\right) v_{\max } \mathrm{cm}^{-1}:$ 3018, 1667, 1609. ${ }^{1} \mathrm{H}-\mathrm{NMR}\left(300 \mathrm{MHz}, \mathrm{CDCl}_{3}\right) \delta: 9.62(1 \mathrm{H}, \mathrm{d}, J=8.1 \mathrm{~Hz}), 7.55$ $(1 \mathrm{H}, \mathrm{dd}, J=15.0,11.7 \mathrm{~Hz}), 6.51(1 \mathrm{H}, \mathrm{d}, J=16.2 \mathrm{~Hz}), 6.34$ $(1 \mathrm{H}, \mathrm{d}, J=16.2 \mathrm{~Hz}), 6.33(1 \mathrm{H}, \mathrm{d}, J=11.7 \mathrm{~Hz}), 6.18(1 \mathrm{H}, \mathrm{dd}$, $J=15.0,8.1 \mathrm{~Hz}), 5.87(1 \mathrm{H}, \mathrm{d}, J=9.6 \mathrm{~Hz}), 5.79(1 \mathrm{H}, \mathrm{dt}, J=9.6$, $4.5 \mathrm{~Hz}), 2.12-2.08(5 \mathrm{H}, \mathrm{m}), 1.89(3 \mathrm{H}, \mathrm{s}), 1.05(6 \mathrm{H}, \mathrm{s}) .{ }^{13} \mathrm{C}-\mathrm{NMR}$ $\left(75 \mathrm{MHz}, \mathrm{CDCl}_{3}\right) \delta: 193.60,147.83,146.53,137.78,135.67$, $131.18,130.76,129.76,128.79,127.80,126.20,39.86,33.98$, 26.71, 20.32, 12.99. HR-ESIMS Calcd for $\mathrm{C}_{17} \mathrm{H}_{23} \mathrm{O}[\mathrm{M}+\mathrm{H}]^{+}$: 243.1743. Found: 243.1741.

(2E,4E,6E,8E,10E)-3,9-Dimethyl-11-(2,6,6-trimethylcyclohexen-1-yl)-2,4,6,8,10-undecapentaen-1-al (A1-10ex, 4a) According to GP2, ethyl (2E,4E,6E,8E,10E)-3,9dimethyl-11-(2,6,6-trimethylcyclohexen-1-yl)-2,4,6,8,10-undecapentaenoate $(820 \mathrm{mg}, 96 \%)$ was obtaind from 10a $(586 \mathrm{mg}$, $2.40 \mathrm{mmol})$, triethyl 3-methyl-4-phosphonocrotonate $(1.77 \mathrm{~g}$, $7.19 \mathrm{mmol}), n$-BuLi $(4.50 \mathrm{~mL}, 1.57 \mathrm{M}$ in hexane, $7.07 \mathrm{mmol})$ and DMPU $(1.10 \mathrm{~mL}, 9.59 \mathrm{mmol})$. Eluent: hexane $/ \mathrm{Et}_{2} \mathrm{O}=8: 1$. 
According to GP3, 4a (235 mg, 36\%, in 3 steps from 10a) was obtained from ethyl $(2 E, 4 E, 6 E, 8 E, 10 E)-3,9$-dimethyl-11-(2,6,6trimethyl-cyclohexen-1-yl)-2,4,6,8,10-undecapentaenoate (709 mg, $2.00 \mathrm{mmol}), \mathrm{LiAlH}_{4}(152 \mathrm{mg}, 4.01 \mathrm{mmol})$ and $\mathrm{MnO}_{2}$ (85\% purity, $7.10 \mathrm{~g}, 69.4 \mathrm{mmol})$. Eluent: hexane $/ \mathrm{Et}_{2} \mathrm{O}=4: 1$.

4a: Orange solid. UV-vis (EtOH) $\lambda_{\max } 403 \mathrm{~nm}(\varepsilon=54000)$. IR $\left(\mathrm{CHCl}_{3}\right) \quad v_{\max } \mathrm{cm}^{-1}: 2926,1651,1599,1561 . \quad{ }^{1} \mathrm{H}-\mathrm{NMR}$ $\left(300 \mathrm{MHz}, \mathrm{CDCl}_{3}\right) \delta: 10.10(1 \mathrm{H}, \mathrm{d}, J=8.1 \mathrm{~Hz}), 6.99-6.78(2 \mathrm{H}$, m), $6.35(1 \mathrm{H}, \mathrm{d}, J=15.0 \mathrm{~Hz}), 6.34(1 \mathrm{H}, \mathrm{dd}, J=15.0,10.5 \mathrm{~Hz})$, $6.27(1 \mathrm{H}, \mathrm{d}, J=15.6 \mathrm{~Hz}), 6.15(1 \mathrm{H}, \mathrm{d}, J=10.5 \mathrm{~Hz}), 6.14(1 \mathrm{H}$, d, $J=15.6 \mathrm{~Hz}), 5.96(1 \mathrm{H}, \mathrm{d}, J=8.1 \mathrm{~Hz}), 2.30(3 \mathrm{H}, \mathrm{s}), 2.02(2 \mathrm{H}$, t, $J=6.3 \mathrm{~Hz}), 1.99(3 \mathrm{H}, \mathrm{s}), 1.72(3 \mathrm{H}, \mathrm{s}), 1.63-1.54(2 \mathrm{H}, \mathrm{m})$, $1.50-1.42(2 \mathrm{H}, \mathrm{m}), 1.03(6 \mathrm{H}, \mathrm{s}) .{ }^{13} \mathrm{C}-\mathrm{NMR}\left(75 \mathrm{MHz}, \mathrm{CDCl}_{3}\right) \delta$ : $191.09,154.56,139.51,137.70,137.23,136.92,134.46,134.23$, $131.59,130.18,129.68,129.14,128.81,39.59,34.26,33.13$, 28.96, 21.76, 19.19, 12.98, 12.79. HR-ESIMS Calcd for $\mathrm{C}_{22} \mathrm{H}_{31} \mathrm{O}$ $[\mathrm{M}+\mathrm{H}]^{+}: 311.2369$. Found: 311.2369.

(2E, $4 E, 6 E, 8 E, 10 E)-3,9-D i m e t h y l-11-(2,6,6$-trimethylcyclohexa-1,3-dien-1-yl)-2,4,6,8,10-undecapentaen-1-al (A210ex, 4b) According to GP2, ethyl $(2 E, 4 E, 6 E, 8 E, 10 E)-3,9-$ dimethyl-11-(2,6,6-trimethylcyclohexa-1,3-dien-1-yl)-2,4,6,8,10undecapentaenoate $(714 \mathrm{mg}$, quant.) was obtained from $\mathbf{1 0 b}$ (450 mg, $1.86 \mathrm{mmol})$, triethyl 3-methyl-4-phosphonocrotonate $(746 \mathrm{mg}, 2.79 \mathrm{mmol}), n-\mathrm{BuLi}(1.74 \mathrm{~mL}, 1.58 \mathrm{M}$ in hexane, $2.79 \mathrm{mmol})$ and DMPU (0.448 mL, $3.71 \mathrm{mmol})$. Eluent: hexane/ EtOAc $=30: 1$. According to GP3, 4b $(127 \mathrm{mg}, 22 \%$, in 3 steps from 10b) was obtained from ethyl $(2 E, 4 E, 6 E, 8 E, 10 E)-3,9$-dimethyl-11-(2,6,6-trimethylcyclohexa-1,3-dien-1-yl)-2,4,6,8,10undecapentaenoate $(714 \mathrm{mg}, 2.02 \mathrm{mmol})$, DIBAL $(7.08 \mathrm{~mL}$, $1.0 \mathrm{M}$ in hexane, $7.08 \mathrm{mmol})$ and $\mathrm{MnO}_{2}(85 \%$ purity, $7.14 \mathrm{~g}$, $69.8 \mathrm{mmol}$ ). Eluent: hexane $/ \mathrm{Et}_{2} \mathrm{O}=5: 1$. Spectral data were shown in the literature. ${ }^{20)}$

(2E, $4 E, 6 E, 8 E, 10 E)-5,9-D i m e t h y l-11-(2,6,6$-trimethylcyclohexen-1-yl)-2,4,6,8,10-undecapentaen-1-al (A1-14ex, 5a) According to GP1, ethyl (2E,4E,6E,8E,10E)-5,9dimethyl-11-(2,6,6-trimethylcyclohexen-1-yl)-2,4,6,8,10-undecapentaenoate $(565 \mathrm{mg}, 96 \%)$ was obtaind from retinal $\left.{ }^{25}\right)$ (2a: $477 \mathrm{mg}, 1.59 \mathrm{mmol})$, triethyl phosphonoacetate $(1.07 \mathrm{~g}$, $4.47 \mathrm{mmol})$ and $\mathrm{NaN}(\mathrm{TMS})_{2} \quad(4.47 \mathrm{~mL}, 1.0 \mathrm{M}$ in THF, $4.47 \mathrm{mmol})$. Eluent: hexane $/$ EtOAc $=9: 1$.

According to GP3, 5a $(82.0 \mathrm{mg}, 19 \%$, in 3 steps from 2a) was obtained from ethyl $(2 E, 4 E, 6 E, 8 E, 10 E)$-5,9-dimethyl11-(2,6,6-trimethylcyclohexen-1-yl)-2,4,6,8,10-undecapentaenoate $(466 \mathrm{mg}, 1.26 \mathrm{mmol}), \mathrm{LiAlH}_{4}(96.0 \mathrm{mg}, 2.52 \mathrm{mmol})$ and $\mathrm{MnO}_{2}$ (85\% purity, $\left.4.60 \mathrm{~g}, 45.0 \mathrm{mmol}\right)$. Eluent: hexane/ $\mathrm{Et}_{2} \mathrm{O}=4: 1$. Spectra data were identical with those of the literature. $^{28)}$

5a: Orange solid. UV-vis (EtOH) $\lambda_{\max } 405 \mathrm{~nm}(\varepsilon=48000)$. IR $\left(\mathrm{CHCl}_{3}\right) v_{\max } \mathrm{cm}^{-1}: 2926,1667,1603,1559 .{ }^{1} \mathrm{H}-\mathrm{NMR}$ $\left(600 \mathrm{MHz}, \mathrm{CDCl}_{3}\right) \delta: 9.61(1 \mathrm{H}, \mathrm{d}, J=7.8 \mathrm{~Hz}), 7.51(1 \mathrm{H}$, dd, $J=15.0,12.0 \mathrm{~Hz}), 6.92(1 \mathrm{H}, \mathrm{dd}, J=14.4,11.4 \mathrm{~Hz}), 6.38$ $(1 \mathrm{H}, \mathrm{d}, J=15.0 \mathrm{~Hz}), 6.35(1 \mathrm{H}, \mathrm{d}, J=12.0 \mathrm{~Hz}), 6.29(1 \mathrm{H}, \mathrm{d}$, $J=16.2 \mathrm{~Hz}), 6.18(1 \mathrm{H}, \mathrm{dd}, J=12.6,7.8 \mathrm{~Hz}), 6.17(1 \mathrm{H}, \mathrm{d}$, $J=12.6 \mathrm{~Hz}), 6.15(1 \mathrm{H}, \mathrm{d}, J=16.2 \mathrm{~Hz}), 2.11(3 \mathrm{H}, \mathrm{s}), 2.04(2 \mathrm{H}$, $\mathrm{t}, J=6.0 \mathrm{~Hz}), 2.01(3 \mathrm{H}, \mathrm{s}), 1.72(3 \mathrm{H}, \mathrm{s}), 1.65-1.58(2 \mathrm{H}, \mathrm{m})$, 1.49-1.45 (2H, m), $1.04(6 \mathrm{H}, \mathrm{s}) .{ }^{13} \mathrm{C}-\mathrm{NMR}\left(150 \mathrm{MHz}, \mathrm{CDCl}_{3}\right)$ $\delta: 193.56,147.64,146.68,139.45,137.75,137.32,135.51,130.77$, $130.15,129.96,129.89,128.72,128.48,39.64,34.29,33.15$, 28.98, 21.77, 19.22, 13.29, 12.93 .

$(2 E, 4 E, 6 E, 8 E, 10 E)-5,9-D i m e t h y l-11-(2,6,6$-trimethylcyclohexa-1,3-dien-1-yl)-2,4,6,8,10-undecapentaen-1-al (A2- 14ex, 5b) According to GP1, ethyl (2E,4E,6E,8E,10E)-5,9dimethyl-11-(2,6,6-trimethylcyclo-hexa-1,3-dien-1-yl)2,4,6,8,10-undecapentaenoate $(115 \mathrm{mg}, 85 \%)$ was obtained from 3,4-didehydroretinal ${ }^{22}$ (2b: $\left.109 \mathrm{mg}, 0.387 \mathrm{mmol}\right)$, triethyl phosphonoacetate (130 mg, $0.581 \mathrm{mmol})$ and $\mathrm{NaH}$ $(60 \%, \quad 23.2 \mathrm{mg}, \quad 0.581 \mathrm{mmol})$. Eluent: hexane $/ \mathrm{Et}_{2} \mathrm{O}=20: 1$. According to GP3, 5b $(64.1 \mathrm{mg}, 54 \%$, in 3 steps from $\mathbf{2 b})$ was obtained from ethyl $(2 E, 4 E, 6 E, 8 E, 10 E)$-5,9-dimethyl11-(2,6,6-trimethyl-cyclohexa-1,3-dien-1-yl)-2,4,6,8,10-undecapentaenoate $(115 \mathrm{mg}, 0.327 \mathrm{mmol})$, DIBAL $(1.31 \mathrm{~mL}, 1.0 \mathrm{M}$ in hexane, $1.31 \mathrm{mmol})$ and $\mathrm{MnO}_{2}(85 \%$ purity, $1.15 \mathrm{~g}, 11.2 \mathrm{mmol})$. Eluent: hexane $/ \mathrm{Et}_{2} \mathrm{O}=5: 1$. Spectral data were shown in the literature. $^{20)}$

Preparation of ChR Analogs and Spectroscopy In this study, two ChR variants, ReaCh (NCBI accession number, KF448069) ${ }^{11)}$ and ChrimsonR (Chrimson (KF992060) K176R mutant $)^{19)}$ were used. These ChR variants were expressed by HEK293 system as reported previously. ${ }^{18)}$ Briefly, the cDNA of these $\mathrm{ChR}$ variants were inserted into the mammalian expression vector $\mathrm{pCAGGS}$ with the epitope sequence of anti-bovine rhodopsin monoclonal antibody rholD4 (ETSQVAPA) on the C-terminus. HEK293 cells transfected with the plasmid bearing the ChR gene were collected after incubation for $2 \mathrm{~d}$, and suspended in Buffer P (50 mM N-(2-hydroxyethyl)piperazine$N^{\prime}$-2-ethanesulfonic acid (HEPES) and $140 \mathrm{mM} \mathrm{NaCl}, \mathrm{pH}$ $6.5)$. Retinal or analog dissolved in ethanol was added to the sample at final concentration of $20 \mu \mathrm{M}$. After overnight incubation at $4{ }^{\circ} \mathrm{C}$, the regenerated pigments were extracted by $1 \%$ $n$-dodecyl- $\beta$-D-maltoside (DDM) in Buffer $\mathrm{P}$, and purified by rholD4-antibody conjugated agarose column. The final solvent of the sample was Buffer P with $0.02 \%$ DDM at $\mathrm{pH}$ 6.5. All the procedures above were performed under deep-red light.

UV-visible absorption spectra of pigments were measured by UV-visible spectrophotometer (Shimadzu UV-2400), which is equipped with a water circulation system to the cell holder to keep the sample at $4{ }^{\circ} \mathrm{C}$. HEK 293 cells produce $\mathrm{A} 1,{ }^{29)}$ which generates approx. 10\% (ReaChR) or approx. 50\% (ChrimsonR) of fully regenerated pigment with excess A1. To show the pure spectra of new ChRs, the contribution of ChR regenerated by the endogenous A1 was subtracted from the sample spectra, and the absorption spectra were normalized to absorbance 1.0 at $278 \mathrm{~nm}$.

Acknowledgments This work was supported in part by JSPS KAKENHI Grant No 26450146 (to AW), The Science Research Promotion Fund from The Promotion and Mutual Aid Corporation for Private Schools of Japan and The Kobe Pharmaceutical Collaboration Fund.

Conflict of Interest The authors declare no conflict of interest.

Supplementary Materials The online version of this article contains supplementary materials.

\section{References \\ 1) Nagel G., Ollig D., Fuhrmann M., Kateriya S., Musti A. M., Bam- berg E., Hegemann P., Science, 296, 2395-2398 (2002). \\ 2) Ernst O. P., Lodowski D. T., Elstner M., Hegemann P., Brown L. S. Kandori H., Chem. Rev., 114, 126-163 (2014). \\ 3) Deisseroth K., Feng G., Majewska A. K., Miesenböck G., Ting A.}


Schnitzer M. J., J. Neurosci., 26, 10380-10386 (2006).

4) Deisseroth K., Nat. Methods, 8, 26-29 (2011).

5) Yizhar O., Fenno L. E., Davidson T. J., Mogri M., Deisseroth K., Neuron, 71, 9-34 (2011).

6) Zhang F., Vierock J., Yizhar O., Fenno L. E., Tsunoda S., Kianianmomeni A., Prigge M., Berndt A., Cushman J., Polle J., Magnuson J., Hegemann P., Deisseroth K., Cell, 147, 1446-1457 (2011).

7) Bi A., Cui J., Ma Y.-P., Olshevskaya E., Pu M., Dizhoor A. M., Pan Z.-H., Neuron, 50, 23-33 (2006).

8) Kravitz A. V., Freeze B. S., Parker P. R. L., Kay K., Thwin M. T., Deisseroth K., Kreitzer A. C., Nature (London), 466, 622-626 (2010).

9) Lin J. Y., Exp. Physiol., 96, 19-25 (2011).

10) Prigge M., Schneider F., Tsunoda S. P., Shilyansky C., Wietek J., Deisseroth K., Hegemann P., J. Biol. Chem., 287, 31804-31812 (2012).

11) Lin J. Y., Knutsen P. M., Muller A., Kleinfeld D., Tsien R. Y., Nat. Neurosci., 16, 1499-1508 (2013).

12) Zhang F., Prigge M., Beyrière F., Tsunoda S. P., Mattis J., Yizhar O., Hegemann P., Deisseroth K., Nat. Neurosci., 11, 631-633 (2008).

13) Sineshchekov O. A., Govorunova E. G., Wang J., Spudich J. L., Biochemistry, 51, 4499-4506 (2012).

14) AzimiHashemi N., Erbguth K., Vogt A., Riemensperger T., Rauch E., Woodmansee D., Nagpal J., Brauner M., Sheves M., Fiala A., Kattner L., Trauner D., Hegemann P., Gottschalk A., Liewald J. F., Nat. Commun., 5, 5810 (2014).

15) Ganapathy S., Bécheau O., Venselaar H., Frölich S., van der Steen J. B., Chen Q., Radwan S., Lugtenburg J., Hellingwerf K. J., de Groot H. J. M., de Grip W. J., Biochem. J., 467, 333-343 (2015).

16) Okitsu T., Matsuyama T., Yamashita T., Ishizuka T., Yawo H., Ima- moto Y., Shichida Y., Wada A., Chem. Pharm. Bull., 65, 356-358 (2017)

17) Wang H., Sugiyama Y., Hikima T., Sugano E., Tomita H., Takahashi T., Ishizaki T., Yawo H., J. Biol. Chem., 284, 5685-5696 (2009).

18) Shen Y. C., Sasaki T., Matsuyama T., Yamashita T., Shichida Y., Okitsu T., Yamano Y., Wada A., Ishizuka T., Yawo H., Imamoto Y., Biochemistry, 57, 5544-5556 (2018).

19) Klapoetke N. C., Murata Y., Kim S. S., et al., Nat. Methods, 11, 338-346 (2014).

20) Takayama R., Kaneko A., Okitsu T., Tsunoda S. P., Shimono K. Mizuno M., Kojima K., Tsukamoto T., Kandori H., Mizutani Y., Wada A., Sudo Y., J. Phys. Chem. Lett, 9, 2857-2862 (2018).

21) Eroglu A., Harrison E. H., J. Lipid Res., 54, 1719-1730 (2013).

22) Bennani Y. L., J. Org. Chem., 61, 3542-3544 (1996).

23) Wada A., Hiraishi S., Takamura N., Date T., Aoe K., Ito M., J. Org. Chem., 62, 4343-4348 (1997).

24) Wada A., Wang F., Ito M., Chem. Pharm. Bull., 56, 112-114 (2008).

25) Hruszkewycz D. P., Cavanaugh K. R., Takamura K. T., Wayman L. M., Curley R. W. Jr., Synthesis, 2011, 2205-2207 (2011).

26) Bassolino G., Sovdat T., Liebel M., Schnedermann C., Odell B., Claridge T. D. W., Kukura P., Fletcher S. P., J. Am. Chem. Soc., 136, 2650-2658 (2014).

27) Colmenares L. U., Liu R. S. H., Tetrahedron, 47, 3711-3718 (1991).

28) Domínguez M., Pequerul R., Alvarez R., Giménez-Dejoz J., Birta E., Porté S., Rủhl R., Parés X., Farrés J., de Lera A. R., Tetrahedron, 74, 2567-2574 (2018)

29) Brueggemann L. I., Sullivan J. M., J. Gen. Physiol., 119, 593-612 (2002). 